The motives behind consumers' intention to use peer-to-peer accommodation: a fsQCA application

De Canio, Francesca ${ }^{\mathrm{a}}$; Nieto-Garcia, Marta ${ }^{\mathrm{b}}$; Martinelli, Elisa ${ }^{\mathrm{c}}$; Pellegrini, Davided ${ }^{\mathrm{d}}$

${ }^{\mathrm{a}, \mathrm{c}}$ University of Modena and Reggio Emilia

${ }^{\mathrm{b}}$ University of Portsmouth

${ }^{\mathrm{d}}$ University of Parma 


\title{
The motives behind consumers' intention to use peer-to-peer accommodation: a fsQCA application
}

\begin{abstract}
Purpose Literature on the motives influencing consumers' intention to use peer-to-peer (P2P) platforms has become vast and fragmented. The purpose of this paper is to shed light on this research stream by applying a novel methodological approach that reveals the existence of alternative combinations of motives that equally boost consumers' intention to use P2P accommodation.
\end{abstract}

Design/Methodology/Approach The methodological approach builds on complexity theory and includes both linear and nonlinear techniques. The empirical analysis combines multiple regression analysis and fuzzy-set qualitative comparative analysis (fsQCA). The sample comprises 458 users of a leading P2P accommodation platform.

Findings The fsQCA reveals four distinct combinations of motives. Social interaction and social esteem, either combined themselves or in partial combination with economic benefits, emerge as two important drivers of behavioral intention to use P2P accommodation. Sustainability appears in three of the combinations.

Originality/value The paper contributes to the $\mathrm{P} 2 \mathrm{P}$ accommodation literature by adopting a novel methodological approach that shows the complexity behind consumers' intention to use P2P accommodation. Consumer motives cannot be considered as separate entities since their effect on consumer intention depends on the interplay among them. Therefore, the different combinations of motives should be managed simultaneously.

Keywords Peer-to-peer accommodation, Complexity theory, Economic benefit, Social interaction, Social esteem, Sustainability

Paper type Research Paper 


\section{Introduction}

"Systems are irreducible to elementary laws or simple processes" (Urry, 2005, p.3)

Digitalization has contributed to the spread of peer-to-peer $(\mathrm{P} 2 \mathrm{P})$ sharing platforms that have reshaped the way people acquire and consume goods and services (Botsman and Rogers, 2010). As a result, a new business model emerged, the so-called "collaborative consumption" (Belk, 2014). This model focuses on the value created by consumers when sharing goods and services and considers their dual role as providers and users, with transactions between peers mediated by a digital platform (Benoit et al., 2017; Heo, 2016). Although operating in multiple sectors, P2P platforms are strongly influencing the hospitality industry (Liu et al., 2019). Airbnb in particular is widely considered as an innovative and disruptive accommodation provider, strongly reshaping the equilibrium of the industry (Price and Belk, 2016). Indeed, as shown by a number of systematic reviews in the field (e.g., Cheng, 2016; Prayag and Ozanne, 2018; Sainaghi and Baggio, 2019), P2P accommodation platforms have remodeled the traditional balance in the industry.

The P2P accommodation phenomenon has been studied in the literature from different points of view: regulations (Williams and Horodnic, 2017); price and revenues (Gričar and Bojnec, 2019; Guttentag and Smith, 2017; Zervas et al., 2017); economic impact on the traditional offer (Heo, 2016; Möhlmann, 2015); and consumer choice motives (Botsman and Rogers, 2010; Guttentag, 2015; Guttentag et al., 2018; Pappas, 2017; Piscicelli et al., 2015). Although explored from different perspectives, the $\mathrm{P} 2 \mathrm{P}$ accommodation phenomenon requires further investigation, as the literature is still fragmented (Dolnicar, 2019; Sainaghi et al., 2020). As suggested by some of the latest works (Altinay and Taheri, 2019; Prayag and Ozanne, 2018; Sainaghi et al., 2020; Yan, 2020), recently academics have shown more interest in understanding how the multitude of motives for the use of $\mathrm{P} 2 \mathrm{P}$ accommodation can be combined. 
This study aims to shed some light on the interplay of the various motives behind the use of P2P accommodation. Building on complexity theory (Anderson, 1999) and adopting a novel methodological approach, this study contributes to the literature in a number of ways. First, the research applies complexity theory to the $\mathrm{P} 2 \mathrm{P}$ accommodation phenomenon, thus providing unique and innovative insights (Altinay and Taheri, 2019). More specifically, this work illustrates the suitability of complexity theory for unveiling how distinct combinations of motives can equally contribute to boosting consumers' intention to use P2P accommodation. Second, the study offers a solid methodological contribution by combining linear (i.e., regression analysis) and nonlinear techniques (i.e., contrarian case analysis and fuzzy-set qualitative comparative analysis), showing that a single methodology might limit the overall findings when it comes to complex phenomena. Finally, the study provides a sound understanding of the four combinations, thus enriching the literature on P2P accommodation. By shaping different combinations, economic benefits, social interaction and social esteem attributes prompt consumers to use $\mathrm{P} 2 \mathrm{P}$ accommodation. Interestingly, sustainability plays a secondary role, leading to consumer intention only when combined with other motives.

From a managerial point of view, the findings have clear implications for practice. The findings will guide both $\mathrm{P} 2 \mathrm{P}$ accommodation providers and $\mathrm{P} 2 \mathrm{P}$ platforms in defining strategies to customize and promote their offer, thus paving the way for the positioning of new P2P-based business models.

\section{Theoretical background}

The collaborative consumption literature (Belk, 2014) investigates "the peer-to-peer based activity of obtaining, giving, or sharing the access to goods and services, coordinated through community-based online services" (Hamari et al., 2016, p.1). Originally prompted by the "natural behavioural instinct of sharing and exchanging" (Botsman and Rogers, 2010, p.213), 
the motivations to engage in collaborative consumption practices are manifold, economic benefits, social interaction, social esteem and sustainability being those most investigated in the literature.

\subsection{Economic benefits}

$\mathrm{P} 2 \mathrm{P}$ sharing platforms have played a strategic role in supporting the exchange of resources among consumers (Belk, 2010). When studying consumers' motivations to use these platforms, economic gains play a key role (Hamari et al., 2016; Liang et al., 2018; Möhlmann, 2015; Tussyadiah, 2016). As noted by Pellegrini and De Canio (2019), the economic value of a transaction in the sharing economy is twofold, since the consumer may act as provider or user of the resource. Economic savings are therefore one of the key motives of engaging in $\mathrm{P} 2 \mathrm{P}$ exchanges (Albinsson and Perera, 2018). In the P2P accommodation domain, P2P accommodation platforms offer a value proposition to both parties (i.e., host and guest). Guests are offered a value-added accommodation experience, and value-for-money is seen as one of the key benefits of this form of accommodation (Dolnicar, 2019). Guttentag and Smith (2017) found that Airbnb prices are preferred over prices of three different hotel categories (i.e., hostel, budget hotel and midrange hotel). Indeed, P2P accommodation platforms offer a democratic economic access to accommodation at high-quality levels (Ju et al., 2019; Lutz and Newlands, 2018).

\subsection{Social interaction}

Consumer participation in the sharing economy is encouraged by the opportunity to socially interact and share (Arnould and Rose, 2016; Belk, 2010; Heo, 2016). According to the social exchange theory (Cropanzano et al., 2017), people exchange social and material resources as a form of social interaction. The social benefits of $\mathrm{P} 2 \mathrm{P}$ exchanges are particularly salient in the 
P2P accommodation domain (Ert et al., 2016; Nieto-Garcia et al., 2019; Tussyadiah, 2016). P2P platforms facilitate social interaction by the sharing of common spaces (e.g., the house or bedroom) between providers and users (Pellegrini and De Canio, 2019), becoming "site[s] of social intensification" (Kennedy, 2016, p.1). Thus, social interaction and exchange are becoming key instruments to living a seamless experience with the support of hosts, locals and citizens of the surrounding areas (Belarmino et al., 2019; Birinci et al., 2018; Lutz and Newlands, 2018; Pellegrini and De Canio, 2019). Accordingly, P2P accommodation facilitates customer interaction with locals, supporting social bonds, unlike standard hotels (Buhalis et al., 2019).

\subsection{Social esteem}

Since Maslow's hierarchy of human needs (1958), the concept of social esteem has played a relevant role in the literature as a determinant of consumer behavior. The emergence of online communities has expanded the boundaries of the group to which a person belongs, making social esteem increasingly relevant (Luca, 2016). Similarly, in the P2P marketplace, the online social esteem of the peer is a key driver for the sharing activity (Hamari et al., 2016; Mauri et al., 2018). Online reputation in the form of ratings may act as a lever of social esteem (Chen and Chang, 2018). In P2P accommodation platforms, both hosts and guests undertake a review process to evaluate their reciprocal experience. Online reputation thus facilitates the relationship between parties (Abrate and Viglia, 2019; Ert et al., 2016; Mauri et al., 2018), and may lead to social esteem gains.

\subsection{Sustainability}

The emergence of environmentally conscious consumer groups reflects how consumers are acting to preserve the environment (Albinsson and Perera, 2018). In line with this, P2P 
platforms allow an efficient use of resources (goods and services) with a relative reduction in waste (Egea and Frutos, 2013). The literature is rich in studies finding collaborative consumption as being partly driven by the desire to protect the environment (e.g., Hamari et al., 2016; Piscicelli et al., 2015). Consumers consider consumption-by-sharing to be a way of preserving society (Lamberton and Rose, 2012), using their resources efficiently (Tussyadiah, 2016) and redistributing surplus with other "electronically connected users" (Albinsson and Perera, 2018, p.46). P2P sharing platforms provide a sustainable and environmentally friendly consumption option in the marketplace (Hamari et al., 2016; Lutz and Newlands, 2018). Although the sustainability roots of collaborative practices are well established, recent studies call for more research on this topic (Prayag and Ozanne, 2018). The large scale of some P2P platforms (e.g., Airbnb and Uber) is upsetting the sustainability ideology on which collaborative consumption is grounded (Martin, 2016). Recent studies in the P2P accommodation context suggest that sustainable consumption behaviors result in improved objective sales performance (e.g., Wang et al., 2019). Accordingly, the environmental sustainability perception of P2P accommodation is still a topic for debate and further research exploring this claim is required (Dolnicar, 2019).

\section{Complexity theory and proposed tenets}

\subsection{The complexity of consumer motives in the P2P domain}

The literature has extensively investigated motives behind consumers' intention to use P2P accommodation. Table I shows the presence of contrary findings. In this regard, applying complexity theory to the $\mathrm{P} 2 \mathrm{P}$ phenomenon can "provide significant information concerning the way that behavioural patterns are formulated and expressed leading to a better understanding of the changing dynamics of tourism" (Pappas, 2017, p.2304). Due to its explanatory power with respect to complex phenomena, this theory has been applied to different topics in the 
marketing and tourism domain (e.g., Hsiao et al. 2015; Woodside, 2014). Specifically, Olya and Altinay (2016) have applied this theory to the understanding of patterns that influence travelers' purchasing intentions and word-of-mouth. Yadav et al. (2019) also adopted this theory to study the combined effect of a number of factors (i.e., biospheric value, green trust, willingness to pay premium, attitude, subjective norms, and perceived behavioral control) on green hotel intentions. Pappas (2017) analyzed a combination of attributes influencing P2P accommodation purchasing intention. In a subsequent study, the author (Pappas, 2019) combined perceived risks, marketing and advertising, social aspects, and price and quality with demographics (i.e., age and income) to derive an overall perception of tourists using P2P accommodation. Olya et al. (2018) analyzed the combination of host attributes and the levels of perceived charm, convenience, and service features to predict $\mathrm{P} 2 \mathrm{P}$ accommodation adoption by disabled tourists. All these studies show that consumers' motives are not unique and usually require to be managed jointly. Nevertheless, the application of complexity theory in the tourism and hospitality sector, with a specific focus on $\mathrm{P} 2 \mathrm{P}$ accommodation, is still limited and it would be useful to explain the recent changes witnessed by the sector (Pappas, 2019).

[Table I to be inserted here]

\subsection{Complexity theory}

The modern complexity theory evolves from the former theory of chaos, with the idea that systems with complex characteristics can be predicted by multi-element patterns (Anderson, 1999). Indeed, this theory considers complex phenomena (i.e., not determined by uncertainty and nonlinearity, and accordingly impossible to explain) as the result of alternative combinations of attributes that lead to the same outcome, i.e., the complex phenomenon (Urry, 2005). Accordingly, when considering a complex phenomenon, the application of linear analysis does not lead to the identification of the antecedents of the phenomenon. The linear 
analysis identifies the main positive or negative effect of the $\mathrm{X} \rightarrow \mathrm{Y}$ relation, which does not always lead to a clear understanding of the phenomenon. Conversely, with the application of nonlinear analyses, it is possible to identify multiple combinations of attributes that explain the complex phenomenon under investigation. Within the same context there might be cases in which $\mathrm{X}$ relates to $\mathrm{Y}$ positively, other cases in which $\mathrm{X}$ relates to $\mathrm{Y}$ negatively and cases in which $\mathrm{X}$ does not relate to $\mathrm{Y}$ at all (Woodside, 2014). Accordingly, the application of complexity theory can "uncover how combinations of causal attributes can lead to the same outcome (equifinality)" (Gligor et al., 2019, p.64). This paper builds upon existing literature and explores the complexity behind alternative combinations of motives that equally lead to increased intention to use $\mathrm{P} 2 \mathrm{P}$ accommodation.

\subsection{Tenets}

In line with complexity theory, which assumes that complex systems operate with nonlinear dynamics (Pappas, 2019), we operationalize possible alternative attributes that can lead equally to the adoption of $\mathrm{P} 2 \mathrm{P}$ accommodation (equifinality). Specifically, our study aims to analyze the complex combination of economic benefits, social interaction, social esteem and sustainability motives, which jointly influence consumer intention to use $\mathrm{P} 2 \mathrm{P}$ accommodation (Figure 1). The binary state combinations (presence or absence) of each of the four motives are examined. Building upon complexity theory, the following tenets are proposed:

T1. A single attribute (i.e., economic benefits, social interaction, social esteem, sustainability) can contribute positively or negatively to consumer intention to use $\mathrm{P} 2 \mathrm{P}$ accommodation depending on the presence or absence of alternative attributes. 
T2. The intention to use $\mathrm{P} 2 \mathrm{P}$ accommodation can stem from a single attribute only with the absence of the remaining attributes.

T3. Alternative configurations of attributes can lead equally to the intention to use P2P accommodation (i.e., equifinality principle).

[Figure 1 to be inserted here]

\section{Methods}

This study adopts a novel methodological design in order to investigate the proposed tenets. First, an exploratory regression analysis is performed to have a preliminary understanding of the main motives behind consumers' choices. Second, nonlinear analyses (contrarian case analysis and fuzzy-set comparative qualitative analysis (fsQCA)) uncover the different combinations leading to consumer intention to use P2P accommodation (Woodside, 2016, p.366). The configurational comparative methodology allows the capture of alternative combinations of causally relevant attributes able to generate a specific outcome (Ragin, 2008). Following previous studies, this study adopts a multistep approach (Ordanini et al., 2014; Russo et al., 2016).

\subsection{Exploratory regression analysis}

First, an exploratory regression analysis assesses the explanatory power of the individual motives on the intention to use $\mathrm{P} 2 \mathrm{P}$ accommodation, considered as the dependent variable. The four main motives that emerge from the literature review were included in the analysis as independent variables while controlling for a number of additional factors (i.e., service quality and sociodemographic variables). Equation 1 shows the analytical form of the regression:

$\mathrm{INT}=\alpha+\beta_{1} * \mathrm{EC}+\beta_{2} * \mathrm{SOC}+\beta_{3} * \mathrm{EST}+\beta_{4} * \mathrm{SUS}+\beta_{5} * \mathrm{SQ}+\beta_{6} * \mathrm{AGE}+\beta_{7} * \mathrm{SEX}+\mathrm{e}$ 
where EC stands for economic benefits, SOC represents social interaction, EST stands for social esteem, SUS is sustainability. The control variables included in the regression analysis are service quality (SQ), age (AGE) and sex (SEX).

\subsection{Contrarian case analysis}

"Contrarian cases" are individuals (e.g., respondents, firms or nations) having an antecedent condition with a negative (positive) association with an outcome condition, while the majority of other cases show a positive (negative) antecedent-outcome main-effect relationship (Hsiao et al., 2015, p.610). Previous studies have proved that, in complex systems, the unique use of symmetric analyses fails to recognize contrarian cases, which leads to severe contribution limitations (Hsiao et al., 2015). As suggested by recent studies (Dolnicar, 2019; Prayag and Ozanne, 2018), the literature addressing consumers' motivations to use P2P accommodation presents contrary findings that require further research. Therefore, this study applies contrarian case analysis in order to examine the presence of contrarian cases in the relationship between the different motives and intention to use $\mathrm{P} 2 \mathrm{P}$ accommodation

\section{3. fs $Q C A$ procedure}

For the fuzzy-set qualitative comparative analysis (fsQCA) we first define the property space, which delineates all the possible combinations of attributes that can generate a specific outcome. The property space consists of the binary possible combinations (presence/absence) of the predictors of the outcome $\left(2^{5}=32\right)$. Following the standard procedure suggested by Ordanini et al. (2014), we calibrate the 1-7 point Likert scales with a conventional fuzzy-set calibration approach. As the literature offers no indication for any possible crossover point, membership is calibrated with a conventional set-membership calibration procedure for configuration analysis, as follows: full membership was fixed at the value of 6 , non- 
membership at 2 and the indifference point at 4 (Ordanini et al., 2014; Russo and Confente, 2019). The truth table is then refined on the basis of frequency and consistency criteria (Russo et al., 2016). As the data set consists of more than 50 responses, the fuzzy-set analysis was set on a minimum of at least four best-fit cases. The "quasi-sufficiency" threshold value of 0.8 was considered as the minimum value for the consistency of our QCA analysis (Ragin, 2008).

\subsection{Research setting and data collection}

The empirical setting for the study is the P2P accommodation sector - specifically, Airbnb, the leading P2P platform. With over seven million global listings across more than 200 countries (Airbnb, 2020), Airbnb offers a suitable research setting. The unprecedented growth of users and the global presence of the platform has transformed Airbnb, which is having a significant effect on the performance of traditional players operating in the travel marketplace (Zervas et al., 2017).

The participants of the study are users of Airbnb in Italy. The Italian Airbnb community is amongst the largest Airbnb communities worldwide (Airbnb, 2016); therefore, this empirical setting seems adequate for the purpose of this study. The structured questionnaire was distributed by Qualtrics via email. The email did not contain any specific reference to the subject of the study in order to reduce self-selection bias (Mody et al., 2017). To participate, the respondents must have used Airbnb in the previous six months, with a minimum of $1-2$ experiences per year. As Table II shows, the sample $(n=458)$ is mainly composed of men (57.4\%) aged 38 years old on average (min. 18, max. 72 years). Younger users (18-35 years old) make up $46.50 \%$ of the sample. In terms of platform usage, only $26.35 \%$ of respondents use Airbnb for stays of less than two nights; on average, people spend 4 nights per stay.

[Table II to be inserted here] 


\subsection{Measures}

The first section of the questionnaire contains measurement items adapted from extant literature on collaborative consumption, as illustrated in Table III. The intention to use Airbnb is measured using three items from Hamari et al. (2016). Measures of social interaction are adapted from Tussyadiah (2016). Sustainability and economic benefits are measured following the work of Hamari et al. (2016) and Tussyadiah (2016), respectively. Social esteem items are adapted from Hamari et al. (2016). Finally, the service quality scale comes from Möhlmann (2015). Items were measured using a 7-point Likert scale anchored by "strongly disagree - 1" and "strongly agree - 7". We used double translation, English-Italian and Italian-English, to reduce translation errors. The second section of the questionnaire measures the sociodemographic characteristics of respondents. The structured questionnaire was pretested on a small sample of 50 panelists to verify the comprehensiveness of the questionnaire and the time required to fill it in.

The values for the Cronbach's alphas, ranging from .82 to .86 , confirm satisfactory reliability for all scales. The average variance extracted (AVE) and the composite reliability (CR) indicators are both higher than the thresholds cited in the relevant literature (AVE $>0.5$ and $\mathrm{CR}>0.7$ ), supporting the convergent validity of the constructs (see Table III).

[Table III to be inserted here]

\section{Results}

\subsection{Exploratory regression analysis}

The exploratory regression analysis shows preliminary evidence on how each motive explains the dependent variable. Table IV presents the results of the analysis. The table shows that economic benefits and social interaction have a positive impact on the intention to use Airbnb $(\mathrm{p}<.01)$. Social esteem also has a positive effect on the dependent variable $(\mathrm{p}<.05)$. 
Interestingly, sustainability does not contribute to explaining the intention to use Airbnb (p> .05). The nonsignificant impact of sustainability is contrary to previous studies considering sustainable consumption as one of the main pillars for the spread of sharing platforms (e.g., Lutz and Newlands, 2018). This result adds evidence to the complex nature of the topic and stresses the need for further analyses.

[Table IV to be inserted here]

\subsection{Contrarian case analysis}

In light of the regression results, we apply the contrarian case analysis to examine the presence of contrarian cases in the relationship between sustainability and intention to use $\mathrm{P} 2 \mathrm{P}$ accommodation. Following the procedure proposed by Woodside (2014), we transform the sustainability construct, which in our analysis is the antecedent condition (A), and the intention to use Airbnb, which in our analysis is the outcome condition $(\mathrm{O})$, into quintiles. Results of the contingency table performed using the software SPSS (Figure 2) show that although in 58.2\% of cases the relationship between $\mathrm{X} \rightarrow \mathrm{Y}$ is symmetric, $10.5 \%$ are negative contrarian cases and $2.8 \%$ are positive contrarian cases. Therefore, in the latter instance, higher levels of sustainability lead to lower levels of intention to use Airbnb, which supports T1. Results highlight that the combination of positive contrarian cases, negative contrarian cases and main effect cases explain the nonsignificant effect in the regression analysis.

[Figure 2 to be inserted here]

\section{3. fs QCA and configurational comparative analysis}

Applying the fsQCA to our data, four highly informative possible configurations (Table V) with a consistency coefficient close to 0.99 were identified. These configurations jointly explain $84 \%$ of consumer intention to use Airbnb. Table V summarizes the fsQCA results, indicating 
with the black circle $(\bullet)$ the presence of the condition, and with the crossed circle $(\Theta)$ its absence. A blank cell was used to indicate the do not care condition, (i.e., "the specific condition is not considered in a solution" - Russo and Confente, 2019, p.135).

[Table $\mathrm{V}$ to be inserted here]

Results of the fsQCA procedure show that alternative combinations of motives similarly lead to high consumer intention to use Airbnb accommodation. Configuration 1 is the combination of attributes with the lowest coverage. It shows a group of consumers accessing Airbnb only because of service quality (raw coverage is 0.14 compared with the 0.71 of the other configurations). The remaining motives are not relevant for these users. Therefore, this result supports T2. Configurations 2, 3 and 4 represent the combinations of attributes with the highest coverage and leading to high levels of intention to use Airbnb. The three configurations support T3. Indeed, a complex phenomenon, such as P2P accommodation usage, is moved by a combination of motives that jointly influence consumers' intention. Social interaction and social esteem, either combined themselves or in partial combination with economic benefits, emerge as two important drivers of behavioral intention to use $\mathrm{P} 2 \mathrm{P}$ accommodation. Sustainability appears in three of the combinations, and it plays a complementary role, leading to consumer intention only when combined with other motives. It is important to note that service quality does not allow discriminating among the alternative combinations since it appears across all four as a necessary condition.

\section{Discussion and Conclusions}

\subsection{Conclusions}

The spread of P2P sharing platforms is making the collaborative consumption phenomenon much more complex than in the past, opening it up to new theoretical, empirical and 
methodological debate. The global dimension of some P2P platforms has greatly shaped the nature of $\mathrm{P} 2 \mathrm{P}$ exchanges, which often differs from the collaborative consumption original stands (Reinhold and Dolnicar, 2018). While the P2P business model is transforming transactions across a number of industries, the hospitality sector is clearly one of the most affected (Benítez-Aurioles, 2019; Liu et al., 2019). Previous studies analyzing the P2P accommodation literature showed that the success factors for the diffusion of this business model lie in the lower pricing, in the provision of a unique experience and in reputation mechanics typical of the online communities (Birinci et al., 2018; Prayag and Ozanne, 2018); nevertheless the literature is still fragmented (Sainaghi et al., 2020). Therefore, a solid understanding of the possible alternative motives moving consumers to increasingly choose these platforms is still needed (Guttentag et al., 2018; Tussyadiah and Pesonen, 2018). Multiple and varied users participate in P2P exchanges, each driven by different motivations (Pesonen and Tussyadiah, 2017). While existing studies investigate isolated drivers and test their individual impact on customer intention, the main contribution of this study is the identification of alternative combinations of drivers that equally lead to customer intention. Therefore, the study provides an innovative perspective to the understanding of $\mathrm{P} 2 \mathrm{P}$ accommodation usage, showing that alternative combinations of motives move consumers to adopt this form of consumption. Overall, the results of the novel methodological approach show that a single methodology might limit the overall findings when it comes to complex phenomena. Three out of four motive combinations show that consumers' intention is determined by the co-existence of at least four motives, which underlie the complexity of the phenomenon. These findings confirm the view of Pappas (2019) on the complexity emerging in the tourism sector and particularly in $\mathrm{P} 2 \mathrm{P}$ accommodation platforms.

\subsection{Theoretical implications}


The study contributes to the literature by drawing on a novel methodological approach in social science and tourism perspectives. Embracing the complexity turn (Urry, 2005), this paper contributes to the academic debate on the interplay of motives affecting customer intention. By doing this, our findings extend previous studies such as Pesonen and Tussyadiah (2017), who identify clusters of users moved by different motives. The present study shows that motives behind the use of $\mathrm{P} 2 \mathrm{P}$ accommodation are mixed in a more complex way, contributing to the understanding of the whole picture of the complex P2P accommodation phenomenon (Sainaghi and Baggio, 2019).

Complexity theory has emerged as an innovative theory in the sharing economy realm (Altinay and Taheri, 2019). Extending recent works that apply the complexity theory to increasingly complex tourism phenomena (e.g., Olya and Altinay, 2016; Olya et al., 2018; Pappas, 2017; 2019; Yadav et al., 2019), the present study shows that linear analyses might be suboptimal when explaining consumers' intention to use P2P accommodation. Results suggest the existence of asymmetrical relationships among key drivers of consumers' intention to use P2P accommodation. Social interaction and social esteem, either combined themselves or in partial combination with economic benefits, seem to be the main drivers of consumer intention to use $\mathrm{P} 2 \mathrm{P}$ platforms, with a greater relevance of the former, confirming the mainstream in the literature (Sainaghi et al., 2020). The salience of social esteem is particularly interesting since most of the studies on P2P transactions have generally overlooked this dimension. Building on the findings of Amaro et al. (2019) and So et al. (2018), our study provides further support for social esteem as a key driver of consumers' intention to use $\mathrm{P} 2 \mathrm{P}$ accommodation. Operating on P2P platforms entails an opportunity to gain social recognition (e.g., via positive ratings) and foster the sense of membership in online communities. This result is in line with recent findings that highlight the importance of self-identity in the P2P domain (Pera et al., 2016). 
Another contribution of the research lies in the investigation of the sustainability motivation (Prayag and Ozanne, 2018). Although sustainability does not result as a relevant motive in the regression analysis, by using contrarian case analysis this study reveals that sustainability motives partially explain consumers' intention to use $\mathrm{P} 2 \mathrm{P}$ accommodation. As confirmed by the fsQCA results, this motive is effectively present across three alternative combinations out of four, representing a secondary motive that, when combined with either economic benefits or social interaction gains, boosts consumers' intention to use P2P accommodation. While numerous studies have neglected the sustainability motive, this study uncovers its presence providing additional support to the findings by Tussyadiah (2016) and Guttentag et al. (2018). Our findings suggest that consumers remain unaware of the detrimental effects of this form of consumption (Nieuwland and van Melik, 2018) and may overestimate its sustainability benefits.

\subsection{Managerial implications}

From a managerial viewpoint, the results are a first attempt to explain how Airbnb reached, equally, more than seven million users globally, with different and in some cases contrary motivations. Despite the fast growth of $\mathrm{P} 2 \mathrm{P}$ accommodation, this study poses some interesting food for thought for operators in the sector. The study suggests that P2P platform providers should pay great attention to the sense of membership and belonging since it improves the personal social esteem of users. Specific actions aligned to this recommendation may include the promotion of high-rated service providers (e.g., featuring hosts in specific destinations). In light of the salience of social interaction, service providers could develop further their interactive tools (e.g., a social chat area) in order to encourage contact between users and service providers. The benefits for the platform would be twofold: first, increased traffic and value for 
the service provider; second, a new source of suggestions to improve the service quality (Dolnicar, 2018).

Another specific measure could be the introduction of an additional badge that serves as a signal of the social proneness of hosts, allowing those who are passionate about social interaction with guests to highlight this trait. Similarly relevant is the concept of sustainability behind the usage of $\mathrm{P} 2 \mathrm{P}$ services, which encourages platform and service providers to develop and promote sustainable solutions. Specifically, a wide-reaching publicity campaign could contribute to the sustainability ethos of Airbnb. In this regard, Airbnb declarations regarding the waste reduction of up to 7,300 tons led to an increased use of the platform (Airbnb, 2016). As found by Palgan et al. (2017), despite the strong investment of the company to improve its sustainable image, sustainability is not yet a strong motivational factor among all users. This result confirms the Hamari et al. (2016) findings that only those who pay attention to ecology choose P2P platforms for sustainability reasons. Finally, the findings also offer some guidelines for traditional hotel managers. Given the emergence of unique motives behind the use of P2P accommodation, they should reshape the value proposition of their offers. In order to compete with $\mathrm{P} 2 \mathrm{P}$ platforms, they must position their offerings as alternatives to $\mathrm{P} 2 \mathrm{P}$ accommodation in the eyes of the consumer. For instance, in terms of the "social interaction" dimension, they could promote direct contact with local people, showing traditions, culture and tastes of the destination area. Providing an authentic experience is one of the main advantages of $\mathrm{P} 2 \mathrm{P}$ accommodation (Birinci et al., 2018).

\subsection{Limitations and future research}

This study is not without limitations. First, this work is based on a cross-sectional empirical analysis in one single country; therefore, the results should be interpreted with caution. Extending the analysis to other countries with different cultural values could enrich this study. 
For instance, social esteem might be even more salient in countries with strong collectivistic values. Similarly, the accommodation sector is unique in that guests' experiences often entail interaction with the host. Other P2P services like car/bike sharing or pet sharing might differ in terms of the key drivers. Therefore, further research across P2P marketplaces would be beneficial. Second, the empirical analysis uses psychometric constructs to measure both motives and behavioral intentions. Accordingly, it would be worthwhile investigating actual economic gains and consumer behavior in future studies. For instance, further research could use an experimental setting to investigate objective measures such as the cost trade-off between renting a P2P room and a hotel room. Finally, it would be useful to combine both settings (i.e., P2P accommodation setting and traditional accommodation) into a single fsQCA study. Adopting a linear/nonlinear approach to compare these settings will enrich our understanding of the similarities and differences between these two accommodation options. 


\section{References}

Abrate, G. and Viglia, G. (2019), "Personal or product reputation? Optimizing revenues in the sharing economy", Journal of Travel Research, Vol. 58 No. 1, pp. 136-148. https://doi.org/10.1177/0047287517741998

Airbnb. (2016), “Overview of the Airbnb community in Italy", http://www.airbnbcitizen.com/wpcontent/uploads/2016/05/overview_of_the_airbnb_community_in_italy.pdf (accessed 24 March 2019).

Airbnb. (2020), “About Us”, https://news.airbnb.com/about-us/ (accessed 24 January 2020).

Albinsson, P. A. and Perera, Y. B. (2018), The rise of the sharing economy: Exploring the challenges and opportunities of collaborative consumption, ABC-CLIO, Santa Barbara, California.

Altinay, L. and Taheri, B. (2019), "Emerging themes and theories in the sharing economy: a critical note for hospitality and tourism", International Journal of Contemporary Hospitality Management, Vol. 31 No. 1, pp. 180-193. https://doi.org/10.1108/IJCHM-02$\underline{2018-0171 .}$

Amaro, S., Andreu, L. and Huang, S. (2019), "Millenials' intentions to book on Airbnb", Current Issues in Tourism, Vol. 22 No. 18, pp. 2284-2298. https://doi.org/10.1080/13683500.2018.1448368

Anderson, P. (1999), "Perspective: Complexity theory and organization science”, Organization Science, Vol. 10 No. 3, pp. 216-232. https://doi.org/10.1287/orsc.10.3.216

Arnould, E. J. and Rose, A. S. (2016), "Mutuality critique and substitute for Belk's 'sharing”", Marketing Theory, Vol. 16 No. 1, pp. 75-99. https://doi.org/10.1177/1470593115572669 
Belarmino, A., Whalen, E., Koh, Y. and Bowen, J. T. (2019), “Comparing guests' key attributes of peer-to-peer accommodation and hotels: Mixed-methods approach”, Current Issues in Tourism, Vol. 22 No. 1, pp. 1-7. https://doi.org/10.1080/13683500.2017.1293623

Belk, R. (2010), “Sharing”, Journal of Consumer Research, Vol. 36 No. 5, pp. 715-734. https://doi.org/10.1086/612649

Belk, R. (2014), "You are what you can access: Sharing and collaborative consumption online", Journal of Business Research, Vol. 67 No. 8, pp. 1595-1600. https://doi.org/10.1016/j.jbusres.2013.10.001

Benítez-Aurioles, B. (2019), "Barcelona's peer-to-peer tourist accommodation market in turbulent times", International Journal of Contemporary Hospitality Management, Vol. 31 No. 12, pp. 4419-4437. https://doi.org/10.1108/IJCHM-01-2019-0090

Benoit, S., Baker, T. L., Bolton, R. N., Gruber, T. and Kandampully, J. (2017), “A triadic framework for collaborative consumption (CC): Motives, activities and resources \& capabilities of actors", Journal of Business Research, Vol. 79 No. 10, pp. 219-227. https://doi.org/10.1016/j.jbusres.2017.05.004

Birinci, H., Berezina, K. and Cobanoglu, C. (2018), “Comparing customer perceptions of hotel and peer-to-peer accommodation advantages and disadvantages", International Journal of Contemporary Hospitality Management, Vol. 30 No. 2, pp. 1190-1210. https://doi.org/10.1108/IJCHM-09-2016-0506

Botsman, R. and Rogers, R. (2010), What's mine is yours: The rise of collaborative consumption. Harper, New York.

Buhalis, D., Harwood, T., Bogicevic, V., Viglia, G., Beldona, S. and Hofhacker, C. (2019), "Technological disruptions in services: Lessons from tourism and hospitality", Journal 
of Service Management, Vol. 30 No. 4, pp. 484-506. https://dx.doi.org/10.1108/JOSM$\underline{12-2018-0398}$

Camilleri, J. and Neuhofer, B. (2017), "Value co-creation and co-destruction in the Airbnb sharing economy", International Journal of Contemporary Hospitality Management, Vol. 29 No. 9, pp. 2322-2340. https://doi.org/10.1108/IJCHM-09-2016-0492

Chen, C. C. and Chang, Y. C. (2018), "What drives purchase intention on Airbnb? Perspectives of consumer reviews, information quality, and media richness", Telematics and Informatics, Vol. 35 No. 5, pp. 1512-1523. https://doi.org/10.1016/j.tele.2018.03.019

Cheng, M. (2016), "Current sharing economy media discourse in tourism", Annals of Tourism Research, Vol. 60, pp. 111-114. https://doi.org/10.1016/j.annals.2016.07.001

Cropanzano, R., Anthony, E. L., Daniels, S. R. and Hall, A. V. (2017), "Social exchange theory: A critical review with theoretical remedies", Academy of Management Annals, Vol. 11 No. 1, pp. 479-516. https://doi.org/10.5465/annals.2015.0099

Dolnicar, S. (2018). Peer-to-peer accommodation networks: Pushing the boundaries. Goodfellow Publishers, Oxford.

Dolnicar, S. (2019), “A review of research into paid online peer-to-peer accommodation: Launching the Annals of Tourism Research curated collection on peer-to-peer accommodation", Annals of Tourism Research, Vol. 75, pp. 248-264. https://doi.org/10.1016/j.annals.2019.02.003

Egea, J. M. O. and Frutos, N. G. (2013), “Toward consumption reduction: An environmentally motivated perspective", Psychology \& Marketing, Vol. 30 No. 8, pp. 660-675. https://doi.org/10.1002/mar.20636 
Ert, E., Fleischer, A. and Magen, N. (2016), “Trust and reputation in the sharing economy: The role of personal photos in Airbnb", Tourism Management, Vol. 55, pp. 62-73. https://doi.org/10.1016/j.tourman.2016.01.013

Gligor, D., Bozkurt, S. and Russo, I. (2019), “Achieving customer engagement with social media: A qualitative comparative analysis approach", Journal of Business Research, Vol. 101 No. 8, pp. 59-69. https://doi.org/10.1016/j.jbusres.2019.04.006

Gričar, S. and Bojnec, Š. (2019), "Prices of short-stay accommodation: Time series of a eurozone country", International Journal of Contemporary Hospitality Management, Vol. 31 No. 12, pp. 4500-4519. https://doi.org/10.1108/IJCHM-01-2019-0091

Guttentag, D. (2015), “Airbnb: Disruptive innovation and the rise of an informal tourism accommodation sector", Current Issues in Tourism, Vol. 18 No. 12, pp. 1192-1217. http://dx.doi.org/10.1080/13683500.2013.827159

Guttentag, D. A. and Smith, S. L. (2017), “Assessing Airbnb as a disruptive innovation relative to hotels: Substitution and comparative performance expectations", International Journal of Hospitality Management, Vol. 64 No. 7, pp. 1-10. http://dx.doi.org/10.1016/j.ijhm.2017.02.003

Guttentag, D., Smith, S., Potwarka, L. and Havitz, M. (2018), "Why tourists choose Airbnb: A motivation-based segmentation study", Journal of Travel Research, Vol. 57 No. 3, pp. 342-359. https://doi.org/10.1177/0047287517696980

Hamari, J., Sjöklint, M. and Ukkonen, A. (2016), “The sharing economy: Why people participate in collaborative consumption", Journal of the Association for Information Science and Technology, Vol. 67 No. 9, pp. 2047-2059. https://doi.org/10.1002/asi.23552 
Hawlitschek, F., Teubner, T. and Gimpel, H. (2018), "Consumer motives for peer-to-peer sharing", Journal of Cleaner Production, Vol. 204, pp. 144-157. https://doi.org/10.1016/j.jclepro.2018.08.326

Heo, Y. (2016), "Sharing economy and prospects in tourism research", Annals of Tourism Research, Vol. 58 No. 5, pp. 166-170. https://doi.org/10.1016/j.annals.2016.02.002

Hsiao, J. P. H., Jaw, C., Huan, T. C. T. and Woodside, A. G. (2015), “Applying complexity theory to solve hospitality contrarian case conundrums", International Journal of Contemporary Hospitality Management, Vol. 27 No. 4, pp. 608-647. https://doi.org/10.1108/IJCHM-11-2013-0533

Johnson, A. G. and Neuhofer, B. (2017), “Airbnb: An exploration of value co-creation experiences in Jamaica", International Journal of Contemporary Hospitality Management, Vol. 29 No. 9, pp. 2361-2376. https://doi.org/10.1108/IJCHM-08-2016$\underline{0482}$

Ju, Y., Back, K. J., Choi, Y. and Lee, J. S. (2019), “Exploring Airbnb service quality attributes and their asymmetric effects on customer satisfaction", International Journal of Hospitality Management, Vol. 77 No. 1, pp. 342-352. https://doi.org/10.1016/j.ijhm.2018.07.014

Kennedy, J. (2016), “Conceptual boundaries of sharing”, Information, Communication \& Society, Vol. 19 No. 4, pp. 461-474. http://dx.doi.org/10.1080/1369118X.2015.1046894

Lamberton, C. P. and Rose, R. L. (2012), "When is ours better than mine? A framework for understanding and altering participation in commercial sharing systems", Journal of Marketing, Vol. 76 No. 4, pp. 109-125. https://doi.org/10.1509/jm.10.0368

Liang, L. J., Choi, H. C. and Joppe, M. (2018), “Understanding repurchase intention of Airbnb consumers: Perceived authenticity, electronic word-of-mouth, and price sensitivity", 
Journal of Travel \& Tourism Marketing, Vol. 35 No. 1, pp. 73-89. https://doi.org/10.1080/10548408.2016.1224750

Liu, Y. L., Yuen, T. W. and Jiang, H. L. (2019), “An experimental study of consumption orientations, environmental sustainability advertising and home-sharing adoption intentions", International Journal of Contemporary Hospitality Management, Vol. 31 No. 12, pp. 4605-4627. https://doi.org/10.1108/IJCHM-12-2018-0968

Luca, M. (2016), "Reviews, reputation, and revenue: The case of Yelp. com. Com”, Harvard Business School NOM Unit Working Paper, (12-016).

Lutz, C. and Newlands, G. (2018), "Consumer segmentation within the sharing economy: The case of Airbnb", Journal of Business Research, Vol. 88 No. 7, pp. 187-196. https://doi.org/10.1016/j.jbusres.2018.03.019

Mao, Z. and Lyu, J. (2017), "Why travelers use Airbnb again? An integrative approach to understanding travelers' repurchase intention”, International Journal of Contemporary Hospitality Management, Vol. 29 No. 9, pp. 2464-2482. https://doi.org/10.1108/IJCHM$\underline{08-2016-0439}$

Martin, C. J. (2016), “The sharing economy: A pathway to sustainability or a nightmarish form of neoliberal capitalism?", Ecological Economics, Vol. 121 No. 1, pp. 149-159. http://dx.doi.org/10.1016/j.ecolecon.2015.11.027

Maslow, A. H. (1958), “A dynamic theory of human motivation”, in C. L. Stacey \& M. De Martino (Eds.), Understanding human motivation (pp. 26-47). Howard Allen Publishers. https://doi.org/10.1037/11305-004

Mauri, A. G., Minazzi, R., Nieto-García, M. and Viglia, G. (2018), “Humanize your business. The role of personal reputation in the sharing economy", International Journal of Hospitality Management, Vol. 73, pp. 36-43. https://doi.org/10.1016/j.ijhm.2018.01.017 
Mody, M. A., Suess, C. and Lehto, X. (2017), "The accommodation experiencescape: A comparative assessment of hotels and Airbnb", International Journal of Contemporary Hospitality Management, Vol. 29 No. 9, pp. 2377-2404. https://doi.org/10.1108/IJCHM09-2016-0501

Möhlmann, M. (2015), “Collaborative consumption: Determinants of satisfaction and the likelihood of using a sharing economy option again", Journal of Consumer Behaviour, Vol. 14 No. 3, pp. 193-207. https://doi.org/10.1002/cb.1512

Nieto-García, M., Muñoz-Gallego, P. A., Viglia, G. and González-Benito, Ó. (2019), “Be social! The impact of self-presentation on peer-to-peer accommodation revenue", Journal of Travel Research. https://doi.org/10.1177/0047287519878520

Nieuwland, S. and van Melik, R. (2018), "Regulating Airbnb: How cities deal with perceived negative externalities of short-term rentals", Current Issues in Tourism, Vol. 23 No. 7, pp. 811-825. https://doi.org/10.1080/13683500.2018.1504899

Olya, H. G. and Altinay, L. (2016), "Asymmetric modeling of intention to purchase tourism weather insurance and loyalty", Journal of Business Research, Vol. 69 No. 8, pp. 27912800. https://doi.org/10.1016/j.jbusres.2015.11.015

Olya, H. G., Altinay Gazi, Z., Altinay Aksal, F. and Altinay, M. (2018), "Behavioral intentions of disabled tourists for the use of peer-to-peer accommodation: An application of fsQCA", International Journal of Contemporary Hospitality Management, Vol. 30 No. 1, pp. 436-454. https://doi.org/10.1108/IJCHM-08-2016-0471

Ordanini, A., Parasuraman, A. and Rubera, G. (2014), "When the recipe is more important than the ingredients: A qualitative comparative analysis (QCA) of service innovation configurations", Journal of Service Research, Vol. 17 No. 2, pp. 134-149. https://doi.org/10.1177/1094670513513337 
Palgan, Y. V., Zvolska, L. and Mont, O. (2017), "Sustainability framings of accommodation sharing", Environmental Innovation and Societal Transitions, Vol. 23, pp. 70-83. https://doi.org/10.1016/j.eist.2016.12.002

Pappas, N. (2017), “The complexity of purchasing intentions in peer-to-peer accommodation”, International Journal of Contemporary Hospitality Management, Vol. 29 No. 9, pp. 2302-2321. https://doi.org/10.1108/IJCHM-08-2016-0429

Pappas, N. (2019), "The complexity of consumer experience formulation in the sharing economy”, International Journal of Hospitality Management, Vol. 77 No. 1, pp. 415-424. https://doi.org/10.1016/j.ijhm.2018.08.005

Pellegrini, D. and De Canio, F. (2019), The new social game. The sharing economy and the Digital Revolution: An insight into changes in consumer habits. Egea, Milano.

Pera, R., Viglia, G. and Furlan, R. (2016), “Who am I? How compelling self-storytelling builds digital personal reputation", Journal of Interactive Marketing, Vol. 35, pp. 44-55. https://doi.org/10.1016/j.intmar.2015.11.002

Pesonen, J. and Tussyadiah, I. (2017), "Peer-to-peer accommodation: drivers and user profiles”. In Collaborative economy and tourism, pp. 285-303. Springer, Cham.

Piscicelli L., Cooper, T. and Fisher, T. (2015), "The role of values in collaborative consumption: Insights from a product-service system for lending and borrowing in the UK”, Journal of Cleaner Production, Vol. 97 No. June, pp. 21-29. https://doi.org/10.1016/j.jclepro.2014.07.032

Prayag, G. and Ozanne, L. K. (2018), "A systematic review of peer-to-peer (P2P) accommodation sharing research from 2010 to 2016: Progress and prospects from the multi-level perspective”, Journal of Hospitality Marketing \& Management, Vol. 27 No. 6, pp. 649-678. https://doi.org/10.1080/19368623.2018.1429977 
Price, L. L. and Belk, R. W. (2016), “Consumer ownership and sharing: Introduction to the issue", Journal of the Association for Consumer Research, Vol. 1 No. 2, pp. 193-197. https://doi.org/10.1086/686270

Ragin, C. C. (2008), Redesigning social inquiry: Fuzzy sets and beyond. University of Chicago Press, Chicago.

Reinhold, S. and Dolnicar, S. (2018), “The sharing economy”, in Dolnicar, S. (Ed.), Peer-toPeer Accommodation Networks: Pushing the Boundaries, Goodfellow Publishers, Oxford, pp. 15-26.

Russo, I. and Confente, I. (2019), "From dataset to qualitative comparative analysis (QCA) Challenges and tricky points: A research note on contrarian case analysis and data calibration", Australasian Marketing Journal, Vol. 27 No. 2, pp. 129-135. https://doi.org/10.1016/j.ausmj.2018.11.001

Russo, I., Confente, I., Gligor, D. M. and Autry, C. W. (2016), “To be or not to be (loyal): Is there a recipe for customer loyalty in the B2B context?", Journal of Business Research, Vol. 69 No. 2, pp. 888-896. https://doi.org/10.1016/j.jbusres.2015.07.002

Sainaghi, R. and Baggio, R. (2019), “Clusters of topics and research designs in peer-to-peer accommodation platforms", International Journal of Hospitality Management, 102393.

Sainaghi, R., Köseoglu, M. A., d'Angella, F. and Mehraliyev, F. (2020), “Sharing economy: A co-citation analysis", Current Issues in Tourism, Vol. 23 No. 8, pp. 929-937. https://doi.org/10.1080/13683500.2019.1588233

So, K. K. F., Oh, H. and Min, S. (2018), "Motivations and constraints of Airbnb consumers: Findings from a mixed-methods approach", Tourism Management, Vol. 67, pp. 224-236. https://doi.org/10.1016/j.tourman.2018.01.009 
Tussyadiah, I. P. (2016), "Factors of satisfaction and intention to use peer-to-peer accommodation", International Journal of Hospitality Management, Vol. 55 No. 4, pp. 70-80. http://dx.doi.org/10.1016/j.ijhm.2016.03.005

Tussyadiah, I. P. and Pesonen, J. (2016), "Impacts of peer-to-peer accommodation use on travel patterns", Journal of Travel Research, Vol. 55 No. 8, pp. 1022-1040. http://dx.doi.org/10.1080/13683500.2016.1141180

Tussyadiah, I. P. and Pesonen, J. (2018), "Drivers and barriers of peer-to-peer accommodation stay-an exploratory study with American and Finnish travellers", Current Issues in Tourism, Vol. 21 No. 6, pp. 703-720. https://doi.org/10.1080/13683500.2016.1141180

Tussyadiah, I. P. and Zach, F. (2017), "Identifying salient attributes of peer-to-peer accommodation experience", Journal of Travel \& Tourism Marketing, Vol. 34 No. 5, pp. 636-652. https://doi.org/10.1080/10548408.2016.1209153

Urry, J. (2005), “The complexity turn”, Theory, Culture \& Society, Vol. 22 No. 5, pp. 1-14. https://doi.org/10.1177/0263276405057188

Varma, A., Jukic, N., Pestek, A., Shultz, C. J. and Nestorov, S. (2016), “Airbnb: Exciting innovation or passing fad?”, Tourism Management Perspectives, Vol. 20, pp. 228-237. https://doi.org/10.1016/j.tmp.2016.09.002

Wang, Y., Xiang, D., Yang, Z. and Ma, S. S. (2019), "Unraveling customer sustainable consumption behaviors in sharing economy: A socio-economic approach based on social exchange theory", Journal of Cleaner Production, Vol. 208, 869-879. https://doi.org/10.1016/j.jclepro.2018.10.139

Williams, C. C. and Horodnic, I. A. (2017), "Regulating the sharing economy to prevent the growth of the informal sector in the hospitality industry", International Journal of 
Contemporary Hospitality Management, Vol. 29 No. 9, pp. 2261-2278. https://doi.org/10.1108/IJCHM-08-2016-0431

Woodside, A. G. (2014), "Embrace perform model: Complexity theory, contrarian case analysis, and multiple realities", Journal of Business Research, Vol. 67 No. 12, pp. 2495 2503. http://dx.doi.org/10.1016/j.jbusres.2014.07.006

Woodside, A. G. (2016), “The good practices manifesto: Overcoming bad practices pervasive in current research in business", Journal of Business Research, Vol. 69 No. 2, pp. 365381. http://dx.doi.org/10.1016/j.jbusres.2015.09.008

Wu, J., Zeng, M. and Xie, K. L. (2017), “Chinese travelers' behavioral intentions toward roomsharing platforms: The influence of motivations, perceived trust, and past experience", International Journal of Contemporary Hospitality Management, Vol. 29 No. 10, pp. 2688-2707. https://doi.org/10.1108/IJCHM-08-2016-0481

Yadav, R., Balaji, M. S. and Jebarajakirthy, C. (2019), "How psychological and contextual factors contribute to travelers' propensity to choose green hotels?", International Journal of Hospitality Management, Vol. 77, pp. 385-395. https://doi.org/10.1016/j.ijhm.2018.08.002

Yan, Q. (2020), "Peer to Peer Accommodation Networks: Pushing the Boundaries", International Journal of Contemporary Hospitality Management, Vol. 32 No. 1, pp. 383386. https://doi.org/10.1108/IJCHM-01-2020-021

Yang, S. B., Lee, K., Lee, H. and Koo, C. (2019), "In Airbnb we trust: Understanding consumers' trust-attachment building mechanisms in the sharing economy", International Journal of Hospitality Management, Vol. 83, pp. 198-209. https://doi.org/10.1016/j.ijhm.2018.10.016 
Zervas, G., Proserpio, D. and Byers, J. W. (2017), "The rise of the sharing economy: Estimating the impact of Airbnb on the hotel industry", Journal of Marketing Research, Vol. 54 No. 5, pp. 687-705. https://doi.org/10.1509\%2Fjmr.15.0204 


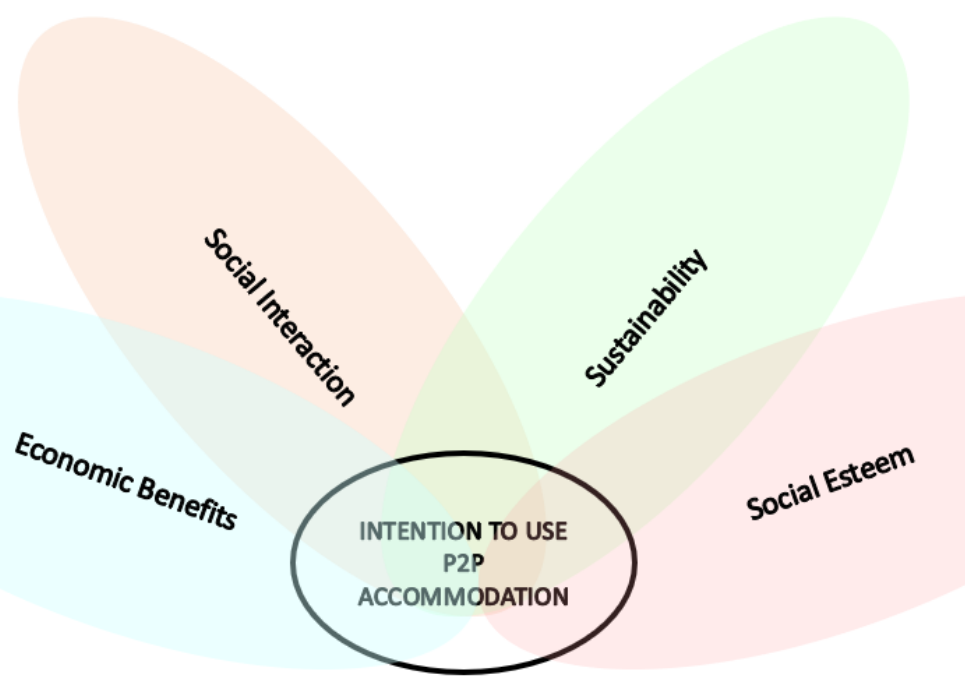

Figure 1. Multidimensional motives behind consumers' intention to use P2P accommodation. 


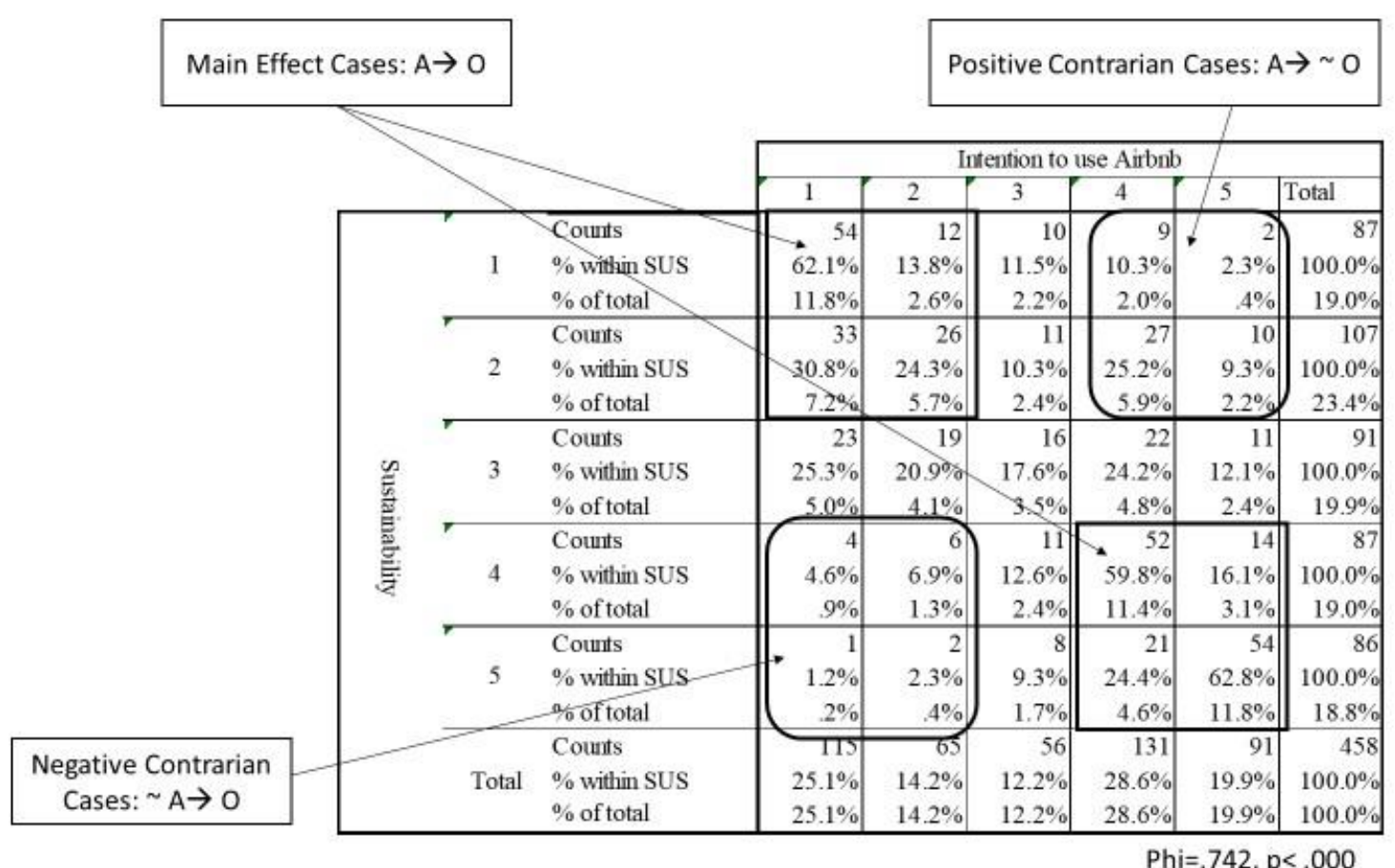

Figure 2. Contrarian cases between intention to use Airbnb and sustainability. 


\begin{tabular}{|c|c|c|c|c|c|c|}
\hline $\begin{array}{c}\text { Academic } \\
\text { papers }\end{array}$ & Economic & $\begin{array}{c}\text { Social } \\
\text { interaction }\end{array}$ & $\begin{array}{c}\text { Social } \\
\text { Esteem }\end{array}$ & Sustainability & Methodology & Findings \\
\hline $\begin{array}{l}\text { Amaro } \text { et } \\
\text { al., } 2019\end{array}$ & YES & & YES & & $\begin{array}{l}\text { Multigroup PLS- } \\
\text { Structural Equation } \\
\text { Modeling on German } \\
(\mathrm{N}=98) \text { and Chinese } \\
(\mathrm{N}=104) \text { Airbnb users }\end{array}$ & $\begin{array}{l}\text { Intentions to book on Airbnb are influenced by subjective norms, } \\
\text { desire for unique accommodation and variety, attitude and } \\
\text { economic benefits. Economic benefits present the smallest effect. }\end{array}$ \\
\hline $\begin{array}{l}\text { Camilleri } \\
\text { and } \\
\text { Neuhofer, } \\
2017\end{array}$ & & YES & & & $\begin{array}{l}\text { Qualitative Online } \\
\text { Content Analysis on } \\
\text { online hosts and guests' } \\
\text { reviews: Airbnb in Malta }\end{array}$ & $\begin{array}{l}\text { Six distinct themes of guest-host social practices of value formation } \\
\text { (e.g. "welcoming"; "helping and interacting"; "recommending"; } \\
\text { and "thanking"). }\end{array}$ \\
\hline $\begin{array}{l}\text { Guttentag, } \\
2015\end{array}$ & YES & YES & & & Literature Review & $\begin{array}{l}\text { Airbnb's distinct appeal, which centers on cost-savings, household } \\
\text { amenities, and the potential for more authentic local experiences. }\end{array}$ \\
\hline $\begin{array}{l}\text { Guttentag et } \\
\text { al., } 2018\end{array}$ & YES & YES & & YES & $\begin{array}{l}\text { Mixed-quantitative } \\
\text { analyses: Exploratory } \\
\text { Factor Analysis, Cluster } \\
\text { Analysis and ANOVA on } \\
923 \text { online surveys } \\
\text { recruited through six } \\
\text { Canadian travel-related } \\
\text { Facebook groups. }\end{array}$ & $\begin{array}{l}\text { Results from factor analysis reveal five motivating factors- } \\
\text { Interaction, Home Benefits, Novelty, Sharing Economy Ethos, and } \\
\text { Local Authenticity. }\end{array}$ \\
\hline $\begin{array}{l}\text { Hawlitschek } \\
\text { et al., } 2019\end{array}$ & YES & YES & YES & YES & $\begin{array}{l}\text { Structural Equation } \\
\text { Modeling on } 745 \text { German } \\
\text { students }\end{array}$ & $\begin{array}{l}\text { Financial benefits, trust in other users, modern lifestyle, effort } \\
\text { expectancy, and ecological sustainability are the main predictors of } \\
\text { peer-to-peer sharing intentions. }\end{array}$ \\
\hline $\begin{array}{l}\text { Johnson and } \\
\text { Neuhofer, } \\
2017\end{array}$ & & YES & & & $\begin{array}{l}\text { Qualitative Online } \\
\text { Content Analysis on } \\
\text { online guests' reviews: } \\
\text { Airbnb in Jamaica }\end{array}$ & $\begin{array}{l}\text { A theoretical framework about host-guest value co-creation } \\
\text { practices. }\end{array}$ \\
\hline $\begin{array}{l}\text { Liang et al., } \\
\quad 2018\end{array}$ & YES & & & & $\begin{array}{l}\text { Structural Equation } \\
\text { Modeling on } 395 \text { US and } \\
\text { Canadian users }\end{array}$ & $\begin{array}{l}\text { Price sensitivity, perceived authenticity and electronic word-of- } \\
\text { mouth positively influence perceived value. Perceived value } \\
\text { positively enhances the repurchase intention. }\end{array}$ \\
\hline $\begin{array}{l}\text { Mao and } \\
\text { Lyu, } 2017\end{array}$ & & & & & $\begin{array}{l}\text { Structural Equation } \\
\text { Modeling on } 624 \text { users }\end{array}$ & Attitude and subject norms positively affect repurchase intention. \\
\hline
\end{tabular}




\begin{tabular}{|c|c|c|c|c|c|c|}
\hline $\begin{array}{l}\text { Mody et al., } \\
\quad 2017\end{array}$ & & & & & $\begin{array}{l}\text { Multigroup Structural } \\
\text { Equation Modeling on } \\
\text { Airbnb's users (N=315) } \\
\text { and hotel's users } \\
(\mathrm{N}=315) \text { in the US }\end{array}$ & $\begin{array}{l}\text { Airbnb outperforms the hotel industry in several experience } \\
\text { dimensions (e.g., serendipity, localness, communitas, and } \\
\text { personalization). }\end{array}$ \\
\hline $\begin{array}{l}\text { Pappas, } \\
2017\end{array}$ & YES & YES & & & $\begin{array}{l}\text { Mixed-Methods: } \\
\text { Regression, Cramer's V } \\
\text { and fsQCA on } 352 \text { Greek } \\
\text { users }\end{array}$ & $\begin{array}{l}\text { Tourism decisions are conditioned by three configurations: socio- } \\
\text { economic orientation, trust formulation and price sensitivity. }\end{array}$ \\
\hline $\begin{array}{l}\text { So } \text { et al., } \\
2018\end{array}$ & YES & YES & YES & & $\begin{array}{l}\text { Mixed-Methods: } 8 \text { semi- } \\
\text { structured Focus Groups } \\
\text { (4 previous Airbnb's } \\
\text { users; 4 Airbnb no users) } \\
\text { + PLS-SEM on } 500 \\
\text { respondents (250 previous } \\
\text { Airbnb's users; } 250 \\
\text { Airbnb no users) }\end{array}$ & $\begin{array}{l}\text { Price value, enjoyment, and home benefits significantly explain the } \\
\text { overall attitude toward Airbnb. Overall attitude, perceived } \\
\text { behavioral control, and subjective norms predict behavioral } \\
\text { intentions. }\end{array}$ \\
\hline $\begin{array}{l}\text { Tussyadiah, } \\
2016\end{array}$ & YES & YES & & YES & $\begin{array}{l}\text { Exploratory Factor } \\
\text { Analysis on } 155 \text { US P2P } \\
\text { accommodations users }\end{array}$ & $\begin{array}{l}\text { The motivations that drive the use of peer-to-peer accommodation } \\
\text { include the societal aspects of sustainability and community, as } \\
\text { well as economic benefits. }\end{array}$ \\
\hline $\begin{array}{l}\text { Tussyadiah } \\
\text { and } \\
\text { Pesonen, } \\
2016\end{array}$ & YES & YES & & & $\begin{array}{l}\text { Regression Analysis on } \\
\text { P2P accommodations } \\
\text { users from US }(\mathrm{N}=155) \\
\text { and Finland }(\mathrm{N}=295)\end{array}$ & $\begin{array}{l}\text { Social and Economic appeals of peer-to-peer accommodation affect } \\
\text { the travel frequency, the length of stay and the range of activities } \\
\text { participated in the tourism destinations. }\end{array}$ \\
\hline $\begin{array}{l}\text { Tussyadiah } \\
\text { and Zach, } \\
2017\end{array}$ & & YES & & & $\begin{array}{l}\text { Cluster and Regression } \\
\text { Analyses on online } \\
\text { guests' reviews: Airbnb in } \\
\text { Portland (USA) }\end{array}$ & $\begin{array}{l}\text { Importance of location, host, and property. P2P accommodation } \\
\text { appeals to consumers who are driven by experiential and social } \\
\text { motivations. }\end{array}$ \\
\hline $\begin{array}{l}\text { Varma et } \\
\text { al., } 2016\end{array}$ & & & & & $\begin{array}{l}\text { Regression Analysis on } \\
347 \text { telephone interviews } \\
\text { of users with previous } \\
\text { experience in online } \\
\text { accommodation booking }\end{array}$ & $\begin{array}{l}\text { There are significant differences between the motivation of } \\
\text { customers that book Airbnb compared to those that book traditional } \\
\text { hotels. The major emerging motivations are recommendations and } \\
\text { service delivery. }\end{array}$ \\
\hline
\end{tabular}




\begin{tabular}{|c|c|c|c|l|l|}
\hline $\begin{array}{c}\text { Wu } \text { et al., } \\
2017\end{array}$ & YES & YES & & $\begin{array}{l}\text { PLS- Structural Equation } \\
\text { Modeling on 445 online } \\
\text { surveys recruited through } \\
\text { five Chinese travel-related } \\
\text { online communities. }\end{array}$ & $\begin{array}{l}\text { Utilitarian motivation, hedonic motivation and perceived trust } \\
\text { positively affect tourists' behavioral intentions. Past experience } \\
\text { with room-sharing moderates these effects. }\end{array}$ \\
\hline $\begin{array}{c}\text { Yang } \text { et al., } \\
2019\end{array}$ & YES & $\begin{array}{l}\text { PLS- Structural Equation } \\
\text { Modeling on P2P } \\
\text { accommodations users } \\
\text { from USA (N=81) and } \\
\text { Korea (N=73) }\end{array}$ & $\begin{array}{l}\text { Based on the trust-building model and attachment theory, the } \\
\text { results indicate that the cognitive factors are more effective than } \\
\text { affective factors in boosting intention to book a P2P } \\
\text { accommodation. }\end{array}$ \\
\hline
\end{tabular}

Table I. Qualitative and quantitative studies measuring motives to use P2P accommodation 


\begin{tabular}{llr}
\hline & & $\mathrm{n}=458$ \\
\hline Gender & Male & $57.4 \%$ \\
& Female & $42.6 \%$ \\
& $<25$ & $9.8 \%$ \\
& $25-35$ & $36.7 \%$ \\
& $36-45$ & $30.4 \%$ \\
& $46-55$ & $16.3 \%$ \\
Income & $>55$ & $6.8 \%$ \\
& $<15.000 €$ & $15.9 \%$ \\
& $15.000-30.000 €$ & $45.7 \%$ \\
& $30.001-45.000 €$ & $18.3 \%$ \\
& $45.001-60.000 €$ & $13.8 \%$ \\
Education & $>60.000 €$ & $6.3 \%$ \\
Level & Primary school & $5.7 \%$ \\
& Secondary school & $43.0 \%$ \\
& University level & $45.2 \%$ \\
& Postgraduate & $6.1 \%$ \\
\hline
\end{tabular}

Table II. Sociodemographic characteristics of the sample 


\begin{tabular}{|c|c|c|c|}
\hline Measures & $\begin{array}{l}\text { Cronbach's } \\
\text { alpha (a) }\end{array}$ & $\begin{array}{l}\text { Average } \\
\text { variance } \\
\text { extracted } \\
\text { (AVE) }\end{array}$ & $\begin{array}{l}\text { Composite } \\
\text { reliability } \\
\text { (CR) }\end{array}$ \\
\hline $\begin{array}{l}\text { Economic Benefits }(\boldsymbol{E B}) \\
\text { I can save money using Airbnb } \\
\text { Airbnb helps in lowering my travel costs } \\
\text { Airbnb makes travel more affordable }\end{array}$ & 0.857 & 0.571 & 0.857 \\
\hline $\begin{array}{l}\text { Social Interaction (SOC) } \\
\text { The use of Airbnb gives me insider tips on local } \\
\text { attractions } \\
\text { Staying at Airbnb accommodation gives me more } \\
\text { meaningful interaction with locals } \\
\text { The use of Airbnb allows me to get to know people from } \\
\text { the local neighborhoods } \\
\text { Airbnb usage helps me connect with locals }\end{array}$ & 0.846 & 0.563 & 0.837 \\
\hline $\begin{array}{l}\text { Social Esteem (EST) } \\
\text { Using Airbnb improves my image within the community } \\
\text { I gain recognition from using Airbnb } \\
\text { I earn respect from others by sharing my Airbnb } \\
\text { experiences with other people } \\
\text { People using Airbnb have more prestige than those who } \\
\text { do not }\end{array}$ & 0.829 & 0.546 & 0.828 \\
\hline Sustainability (SUS) & 0.869 & 0.623 & \\
\hline
\end{tabular}

Airbnb is environmentally friendly

Airbnb helps reduce the negative impact of travel on the environment

Airbnb is efficient in terms of using energy

\begin{tabular}{llll}
\hline Service Quality (SQ) & 0.863 & 0.650 & 0.848 \\
The last Airbnb I slept at / stayed at had good amenities & & & \\
The last Airbnb I slept at / stayed at had good features & & & \\
The last Airbnb I slept at / stayed at was of high quality & & & \\
\hline Intention to use Airbnb (INT) & 0.834 & 0.535 & 0.837
\end{tabular}

Intention to use Airbnb (INT)
I expect to use often Airbnb in the future 
I think I will recommend Airbnb to my friends in the

future

I think I will use Airbnb more in the future

Table III. Measures and construct reliability

\begin{tabular}{|c|c|c|c|c|c|}
\hline \multirow[t]{2}{*}{ Model } & \multicolumn{2}{|c|}{$\begin{array}{l}\text { Unstandardized } \\
\text { coefficients }\end{array}$} & \multirow[t]{2}{*}{$\begin{array}{l}\text { Standardized } \\
\text { coefficients }\end{array}$} & \multirow[b]{2}{*}{$\mathrm{t}$} & \multirow[b]{2}{*}{ VIF } \\
\hline & $\mathrm{B}$ & S.E. & & & \\
\hline Constant & .134 & .208 & & 0.643 & \\
\hline Economic Benefits & .324 & .042 & $.303 * * *$ & 7.773 & 2.060 \\
\hline Social Interaction & .283 & .048 & $.277 * * *$ & 5.883 & 3.005 \\
\hline Social Esteem & .086 & .040 & $.095 * *$ & 2.154 & 2.664 \\
\hline Sustainability & .026 & .035 & .031 & .735 & 2.349 \\
\hline Service Quality & .266 & .040 & $.250 * * *$ & 6.640 & 1.925 \\
\hline Age & -.001 & .002 & -.008 & -.278 & 1.029 \\
\hline Gender & .047 & .049 & .026 & .956 & 1.031 \\
\hline R square & .668 & & & & \\
\hline Adjusted R square & .663 & & & & \\
\hline $\begin{array}{l}\text { Std. error of the } \\
\text { estimate }\end{array}$ & .507 & & & & \\
\hline Durbin-Watson & 1.986 & & & & \\
\hline
\end{tabular}

Table IV. Exploratory regression analysis 


\begin{tabular}{lcccc}
\hline Configurations & 1 & 2 & 3 & 4 \\
\hline Economic Benefits & & $\bullet$ & $\bullet$ & \\
Social Interaction & $\boldsymbol{\Theta}$ & & $\bullet$ & $\bullet$ \\
Social Esteem & $\boldsymbol{\Theta}$ & $\bullet$ & & $\bullet$ \\
Sustainability & $\boldsymbol{\Theta}$ & $\bullet$ & $\bullet$ & $\bullet$ \\
Service Quality & $\bullet$ & $\bullet$ & $\bullet$ & $\bullet$ \\
\hline Raw Coverage & 0.149 & 0.765 & 0.710 & 0.712 \\
Unique Coverage & 0.031 & 0.061 & 0.020 & 0.020 \\
Consistency & 0.984 & 0.992 & 0.996 & 0.996 \\
Solution Coverage & 0.841 & & & \\
Solution Consistency & 0.989 & & & \\
\hline
\end{tabular}

Table V. Configurations of attributes leading to high intention to use Airbnb 